\title{
Nonphytotoxic Aluminum-Peat Complexes Suppress Phytophthora parasitica
}

\author{
E. J. Fichtner, D. L. Hesterberg, and H. D. Shew
}

First and third authors: Department of Plant Pathology, North Carolina State University, Raleigh 27695; and second author: Department of Soil Science, N.C. State University, Raleigh 27695.

Accepted for publication 6 August 2001.

\begin{abstract}
Fichtner, E. J., Hesterberg, D. L., and Shew, H. D. 2001. Nonphytotoxic aluminum-peat complexes suppress Phytophthora parasitica. Phytopathology 91:1092-1097.

Amendment of peat-based potting media with $\mathrm{Al}_{2}\left(\mathrm{SO}_{4}\right)_{3}$ suppresses damping-off of Vinca (Catharanthus roseus) caused by Phytophthora parasitica. The species of aluminum (Al) responsible for disease suppression have not been identified. The objective of this study was to determine the effects of amount and $\mathrm{pH}$ of $\mathrm{Al}_{2}\left(\mathrm{SO}_{4}\right)_{3}$ amendment solutions on survival of $P$. parasitica. In separate experiments, peat was amended with $\mathrm{Al}_{2}\left(\mathrm{SO}_{4}\right)_{3}$ solutions adjusted to $\mathrm{pH} 4$ or 6 at either 0.0158 or $0.0079 \mathrm{~g}$ of $\mathrm{Al}$ per gram of peat. Amended peat was placed in Büchner funnels maintained at $-2.5 \mathrm{kPa}$ matric potential. Peat was infested with $P$. parasitica by placing zero, two, or five colonized Vinca leaf disks in each funnel, and 15 Vinca seeds were placed in each funnel. After $24 \mathrm{~h}$, the matric

potential was brought to $0 \mathrm{kPa}$ to induce zoospore release and returned to $-2.5 \mathrm{kPa}$ after $24 \mathrm{~h}$. Pathogen populations and stand counts were assessed after 2-week incubation. Al amendment solutions at both $\mathrm{pH} 4$ and 6 reduced pathogen populations at $0.0158 \mathrm{~g}$ of Al per gram of peat. Solutions at $\mathrm{pH} 4$ reduced pathogen populations by more than $90 \%$ at both inoculum levels; amendment solutions at $\mathrm{pH} 6$ reduced populations by $95 \%$ at the low inoculum level and $65 \%$ at the high inoculum level. The prevalence of $\mathrm{Al}(\mathrm{OH})_{2}{ }^{+}$in peat amended with $\mathrm{Al}_{2}\left(\mathrm{SO}_{4}\right)_{3}$ solution at $\mathrm{pH} 6$ suggests that ions other than $\mathrm{Al}^{3+}$ may be responsible for pathogen suppression. Based on the difference in chemical conditions of Al-amended peat and suppressive mineral soils, the mechanism of Al-mediated suppression of plant pathogens is speculated to be different in the two systems. Peat containing Al-peat complexes was chemically suppressive to P. parasitica and may confer Al-mediated suppression of plant pathogens with a nonphytotoxic form of Al.
\end{abstract}

Abiotic suppression of plant pathogens by high levels of exchangeable aluminum $(\mathrm{Al})$ has been described in numerous acid mineral soils. Examples of pathogens suppressed by Al include Streptomyces scabies (28), Rhizoctonia solani (20), Fusarium solani (14), Verticillium albo-atrum (30), Thielaviopsis basicola (25-27), Aspergillus flavus (13), Neurospora tetrasperma (21), and multiple Phytophthora spp. (2-4,29). Applications of this Al-mediated suppression have been limited, however, primarily because of potential phytotoxic effects of $\mathrm{Al}$ in mineral soil (32). Studies on disease suppression focused on levels of free ionic $\mathrm{Al}\left(\mathrm{Al}^{3+}\right)$, the most prominent dissolved $\mathrm{Al}$ species at $\mathrm{pH}<4.5$. However, $\mathrm{Al}$ exists in soil as multiple chemical species, including the $\mathrm{pH}$ dependent hydrolysis species $\left(\mathrm{Al}(\mathrm{OH})^{2+}, \mathrm{Al}(\mathrm{OH})_{2}{ }^{+}, \mathrm{Al}(\mathrm{OH})_{3}{ }^{0}\right.$, and $\left.\mathrm{Al}(\mathrm{OH})_{4}^{-}\right)$, referred to as monomeric $\mathrm{Al}$ species (33), $\mathrm{Al}_{13}$ polymers (17), and organically complexed Al (5). Studies have quantified the toxicity of these $\mathrm{Al}$ species to plants $(18,33,38)$, but the influence of $\mathrm{Al}$ species other than $\mathrm{Al}^{3+}$ on fungi is largely unknown.

Al-mediated pathogen suppression has also been observed in a peat-based potting medium (3), where the organic fraction controls the activity of dissolved Al (6). Suppression of Phytophthora parasitica, the causal agent of pre- and postemergence dampingoff of Vinca (Catharanthus roseus), was observed at $\mathrm{pH}>6$, with low levels of exchangeable $\mathrm{Al}(3)$. In this $\mathrm{pH}$ range, the $\mathrm{Al}(\mathrm{OH})_{2}{ }^{+}$ is the primary species in solution (23), and it preferentially binds to organic matter over the $\mathrm{Al}^{3+}$ species (6). The prevalence of organically complexed $\mathrm{Al}$ and $\mathrm{Al}$ hydrolysis species in this system suggests that $\mathrm{Al}^{3+}$ is not solely responsible for pathogen and disease suppression.

Corresponding author: H. D. Shew; E-mail address: david_shew@ncsu.edu

Publication no. P-2001-0831-01R

(C) 2001 The American Phytopathological Society
Addition of organic matter to acid soils decreases the phytotoxicity of $\mathrm{Al}$ by reducing the activity of $\mathrm{Al}$ in the soil solution (38). Because Al binds more strongly to soil organic matter than to the permanent charge sites in a mineral soil $(6,8)$, it was thought to form chelation complexes with aromatic, carboxylate, and hydroxide groups of soil organic matter (37). Titration and electron spin resonance studies, however, suggest that metal ions, including $\mathrm{Cu}, \mathrm{Mn}$, and $\mathrm{Al}$, do not form chelation complexes with functional groups on $\mathrm{H}$-saturated peat and humic acid (5). Most metals, except $\mathrm{Cu}^{2+}(10)$, form outer-sphere (hydrated) complexes with the variable charge carboxylic acid sites of organic matter (5). Because these acid groups have a $\mathrm{pH}$-dependent charge, the binding of $\mathrm{Al}$ varies directly with $\mathrm{pH}(5,15,16)$. Hydrolyzed $\mathrm{Al}$ ions bind more strongly than $\mathrm{Al}^{3+}$ to organic matter $(6,16)$, and the relationship between $\mathrm{pH}$ and $\mathrm{Al}$ adsorption can be modeled with the assumption that $1 \mathrm{~mol}$ of $\mathrm{Al}$ is bound per mole of carboxyl groups (5).

In aqueous solution, the ability of an organic ligand to reduce $\mathrm{Al}$ phytotoxicity is related to the stability of Al-ligand complexes (7). Weak Al complexers, such as phenolics and catechol compounds, have no effect on Al toxicity to plants (7). Short-chained carboxylic acids, however, range from strong to weak in their ability to complex $\mathrm{Al}(7,18)$. Al toxicity to plants is reduced if $\mathrm{Al}$ is strongly bound to soil solids such as organic matter, or if dissolved organic ligands form stable complexes with dissolved $\mathrm{Al}$. The effects of solid-phase and dissolved Al complexes on suppresion of soilborne pathogens have not been quantified.

This research focused on the suppression of $P$. parasitica in peat with organically complexed Al. The objectives of this study were to (i) determine the Al binding capacity of peat, (ii) assess the efficacy of $\mathrm{Al}$ amendment solutions at $\mathrm{pH} 4$ and 6 for control of $P$. parasitica in an organic medium, and (iii) characterize suppression of the pathogen due to physical factors of the peat matrix. 


\section{MATERIALS AND METHODS}

Peat preparation. A dark, commercial grade of Canadian sphagnum peatmoss (Fertiloam, Quebec, Canada) was passed through a sieve with $2 \mathrm{~mm}$ openings and stored dry for subsequent use in all experiments. The $\mathrm{pH}$ of the peat was 3.1 before liming.

Estimation of Al binding capacity. A titration procedure, based on that of Martin and Reeve (24), was used to estimate the number of acid functional groups in the peat that could potentially bind $\mathrm{Al}$. One gram of peat was suspended in $100 \mathrm{ml}$ of $0.05 \mathrm{M}$ $\mathrm{NaCl}$ solution. Peat was solubilized by the addition of $0.1 \mathrm{M} \mathrm{KOH}$ to $\mathrm{pH} 11$, and the suspension was titrated to $\mathrm{pH} 3$ with the gradual addition of $0.05 \mathrm{M} \mathrm{HCl}$. Nitrogen gas was bubbled through the suspension during the titration, and $\mathrm{pH}$ values were determined with a glass, Ross combination $\mathrm{pH}$ electrode attached to an Orion PerpHect LogR meter (Fisher Scientific Co., Norcross, GA). The background solution also was titrated in the absence of peat. The titration was repeated twice with similar results, and an average of the two titrations was used in subsequent calculations. Proton consumption by peat was calculated by subtracting the amount of $\mathrm{H}^{+}$entering solution in the titration of the background solution from the amount of acid added in the peat titration.

Inoculum production. An isolate of $P$. parasitica (isolate 2155 , provided by D. M. Benson, North Carolina State University, Raleigh) obtained from diseased Vinca plants was used as inoculum in all experiments. Leaf disks (1-cm diameter) were cut from mature $C$. roseus cv. Little Bright Eyes plants with a cork borer, placed in a $250-\mathrm{ml}$ beaker containing $100 \mathrm{ml}$ of water and a drop of Tween 80 (Fisher, Norcross, GA), and autoclaved for $30 \mathrm{~min}$ on 2 consecutive days. The sterilized leaf disks were placed on cultures of $P$. parasitica on corn meal agar (Difco Laboratories, Detroit) and incubated for 5 days at room temperature. The colonized leaf disks were removed and used as inoculum. Inoculum levels were varied by adding different numbers of colonized leaf disks to peat contained in Büchner funnels.

Effects of $\mathrm{Al}$ amendment on pathogen populations. Two experiments were conducted to study the effect of $\mathrm{Al}$ on populations of $P$. parasitica. In the first experiment, a $0.05 \mathrm{M} \mathrm{Al}_{2}\left(\mathrm{SO}_{4}\right)_{3}$ solution was adjusted to $\mathrm{pH} 4$, in which $\mathrm{Al}^{3+}$ is the dominant aqueous $\mathrm{Al}$ species (23). In the second experiment, a $0.05 \mathrm{M} \mathrm{Al}_{2}\left(\mathrm{SO}_{4}\right)_{3}$ solution was adjusted to $\mathrm{pH} 6$, in which $\mathrm{Al}(\mathrm{OH})_{2}{ }^{+}$is the dominant aqueous $\mathrm{Al}$ species (23). The $\mathrm{pH}$ adjustments were made by adding $1 \mathrm{~N} \mathrm{KOH}$. In both experiments, $140 \mathrm{~g}$ of sieved peat was placed in each of three plastic bags and mixed thoroughly with $\mathrm{Ca}(\mathrm{OH})_{2}$ at a rate of $0.024 \mathrm{~g} \mathrm{~g}^{-1}$ air-dry peat. The addition of lime ensured that $\mathrm{Ca}$ would not be limiting in the system and raised the $\mathrm{pH}$ from 3.1 to 4.7 . Limed peat was moistened and allowed to equilibrate for 2 days. Peat was amended with three levels of $\mathrm{Al}$ $(0,0.0079$, or $0.0158 \mathrm{~g}$ of $\mathrm{Al}$ per gram of peat) by varying the amount of a $0.05 \mathrm{M} \mathrm{Al}_{2}\left(\mathrm{SO}_{4}\right)_{3}$ solution added to each bag of peat medium. Deionized water was added to achieve a uniform final volume of water $\left(6.8 \mathrm{ml} \mathrm{g}^{-1}\right.$ of peat $)$ in each treatment. Each peat suspension was mixed in a separate plastic bag and incubated at room temperature for 2 days to allow complexation of Al.

Each experiment was a complete factorial with three Al levels $(0,0.0079$, and $0.0158 \mathrm{~g}$ of $\mathrm{Al}$ per gram of peat) and three inoculum levels $(0,2$, or 5 infested leaf disks) in a completely randomized design with four replicate funnels of each treatment. Watersaturated, amended peat was placed in 150-ml fritted-glass Büchner funnels (Fisher Scientific) and was allowed to drain to $-2.5 \mathrm{kPa}$ matric potential $\left(\psi_{\mathrm{m}}\right)$, with respect to the peat surface, by use of hanging water columns. Peat was packed to an average bulk density $\left(D_{b}\right)$ of $0.12 \mathrm{~g} \mathrm{~cm}^{-3}$, resulting in a $3 \mathrm{~cm}$ depth of peat in each funnel. After draining for $6 \mathrm{~h}$, the top $1 \mathrm{~cm}$ of peat was removed from each funnel to obtain samples for chemical analysis, and infested leaf disks and 15 Vinca seeds were placed in each funnel. Inoculum and seed were then covered with the remainder of the previously removed peat, and funnels were covered with plastic bags to prevent evaporation. After incubating seed for $24 \mathrm{~h}$, zoospore release was induced by raising the free-water surface to achieve a $\psi_{\mathrm{m}}$ of $0 \mathrm{kPa}$ (flooding) with respect to the peat surface (22). The water saturation of peat was maintained for $24 \mathrm{~h}$, and the peat was returned to $\psi_{\mathrm{m}}-2.5 \mathrm{kPa}$ for the duration of the experiment.

Two weeks after planting, stand counts and pathogen populations were assessed. The contents of each funnel were placed in individual plastic bags, mixed thoroughly, and a 1-g sample of peat was taken from each bag and suspended in $25 \mathrm{ml}$ of deionized water. Each suspension was spread over five plates of PARP selective medium (19) containing $50 \mu \mathrm{g} / \mathrm{ml}$ of hymexazol (Sankyo Co., Tokyo) and incubated in the dark for 2 days. Plates were then rinsed with deionized water and the colonies of $P$. parasitica were counted. Data were analyzed using the general linear models procedure, and treatment differences were determined with a Waller-Duncan K-ratio test $(\mathrm{K}=100)$ (SAS Institute, Cary, NC). Each experiment was run twice.

Exchangeable Al and pH determination. Peat samples, $3 \mathrm{~g}$ each, were removed from each funnel at the time of planting (initial) and 2 weeks after planting (final). Two samples, one for exchangeable $\mathrm{Al}$ analysis and one for $\mathrm{pH}$ determination, were taken from each funnel. KCl-exchangeable $\mathrm{Al}$ was determined with a modified acid-base titration procedure (39). Each peat sample was suspended in $25 \mathrm{ml}$ of a $1 \mathrm{M} \mathrm{KCl}$ solution for $2 \mathrm{~h}$, filtered through Q5 filter paper (Fisher Scientific), and rinsed three times with $25 \mathrm{ml}$ of $1 \mathrm{M} \mathrm{KCl}$. Ten drops of phenolphthalein solution was added to each extract, and extracts were titrated with $0.1 \mathrm{M} \mathrm{NaOH}$ to a pale pink endpoint. A drop of $0.1 \mathrm{M} \mathrm{HCl}$ was added to return solution to colorless, and then $10 \mathrm{ml}$ of $4 \% \mathrm{NaF}$ was added. In the presence of $\mathrm{Al}$, a stable fluoaluminate complex forms and the pink color returns. Extracts were titrated to a clear endpoint with $0.1 \mathrm{M} \mathrm{HCl}$. Three moles of $\mathrm{H}^{+}$titrate $1 \mathrm{~mol}$ of exchangeable $\mathrm{Al}$ (39). The $\mathrm{pH}$ was determined in a $1: 2(\mathrm{wt} / \mathrm{vol})$ suspension of peat in $0.01 \mathrm{M} \mathrm{CaCl}_{2}$ solution (35). A two-tailed $t$ test was used to compare initial and final values for both exchangeable $\mathrm{Al}$ and $\mathrm{pH}$ within each $\mathrm{Al}$ treatment.

Effect of counter anion on pathogen population. A complete factorial treatment design with two sources of $\mathrm{Al}, 0.05 \mathrm{M} \mathrm{AlCl}_{3}$ and $0.05 \mathrm{M} \mathrm{Al}_{2}\left(\mathrm{SO}_{4}\right)_{3}$ amendment solutions, adjusted to $\mathrm{pH} 4$ and 6 , was used to determine the effect of $\mathrm{Cl}^{-}$and $\mathrm{SO}_{4}{ }^{2-}$ on pathogen population. Peat was amended with $0.0158 \mathrm{~g}$ of $\mathrm{Al}$ per gram of peat, and two infested Vinca leaf disks were placed in each funnel. Each treatment contained four replicates in a completely random design, and the experiment was run twice. The activities of $\mathrm{Al}^{3+}$ and monomeric $\mathrm{Al}$ species in each amendment solution were predicted using GEOCHEM-PC (31), a chemical speciation program. The above procedures for peat amendment, chemical analysis, pathogen population assessment, and data analysis were repeated in this experiment. Correlation between exchangeable $\mathrm{Al}$ and $\mathrm{pH}$ was determined by linear regression analysis.

Zoospore movement. The horizontal movement of zoospores through peat was investigated. Peat was saturated with deionized water and placed in Büchner funnels at $-2.5 \mathrm{kPa} \psi_{\mathrm{m}}$. After $6 \mathrm{~h}$, the sieved peat was packed to an average $D_{b}$ of $0.12 \mathrm{~g} \mathrm{~cm}^{-3}$ to approximate the conditions of $\mathrm{Al}$ amendment experiments. The top $0.5 \mathrm{~cm}$ of peat was removed from the surface of each funnel, and one infested Vinca leaf disk was placed in the center of each funnel. Two-centimeter long stem segments from greenhouse-grown Vinca plants were used as bait for zoospores. Five bait segments were inserted vertically around the inoculum at either 0.5 or $1.0 \mathrm{~cm}$ from the perimeter of the infested leaf tissue. A layer of moist peat was placed over the inoculum, but stem segments were allowed to protrude through the surface for easy removal. Funnels were incubated at $-2.5 \mathrm{kPa} \psi_{\mathrm{m}}$ for $24 \mathrm{~h}$, and the $\psi_{\mathrm{m}}$ was increased to $0 \mathrm{kPa}$ to induce zoospore release. After either 24 or $60 \mathrm{~h}$ of saturation, funnels were returned to $-2.5 \mathrm{kPa} \psi_{\mathrm{m}}$, and stem segment baits were removed and placed on PARP selective medium 
for 4 days in the dark. The number of baits infected with $P$. parasitica from each funnel was determined. The treatment design was a complete factorial with two radial distances, 0.5 and $1.0 \mathrm{~cm}$, and two flood durations, 24 and $60 \mathrm{~h}$. Each treatment had four replicates in a completely random design, and the experiment was con-

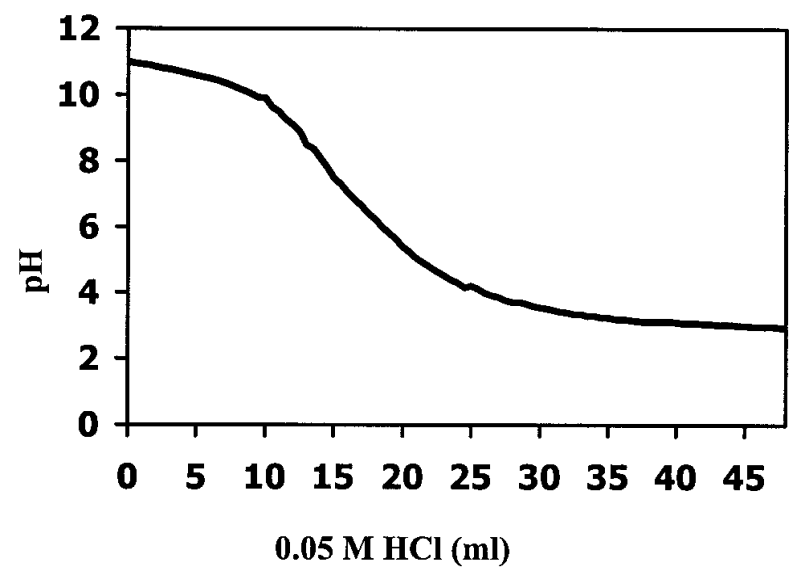

Fig. 1. Titration curve of exchangeable acidity for $1 \mathrm{~g}$ of peat. The proton consumption was calculated as $1.41 \mathrm{mmol} / \mathrm{g}$ of peat in a titration from $\mathrm{pH} 11$ to 3 .

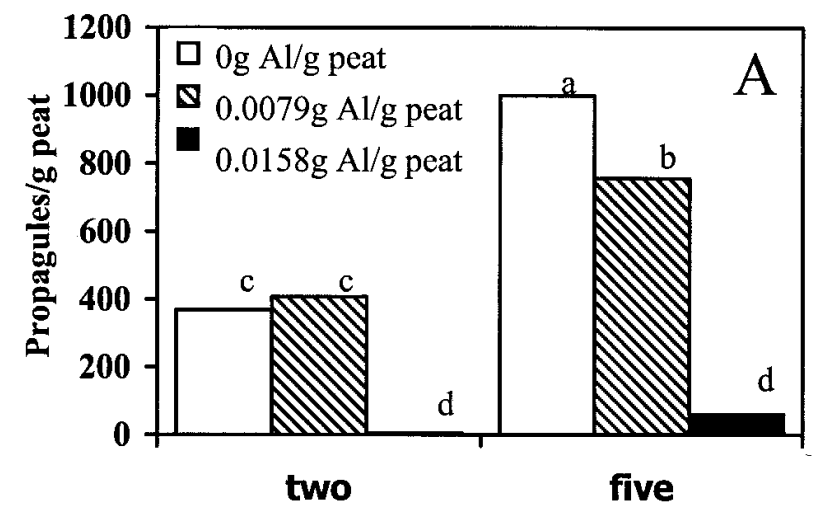

Number of infected leaf disks/ funnel

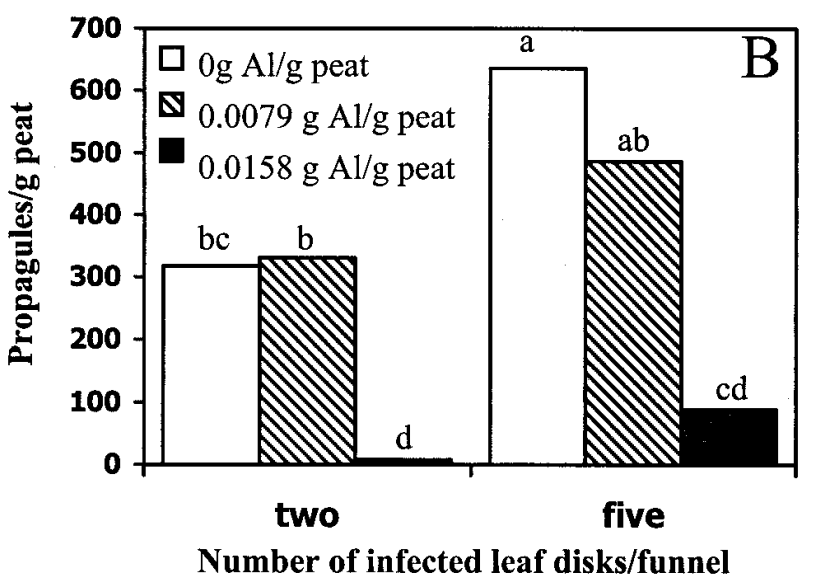

Fig. 2. Assays of Phytophthora parasitica populations were conducted 2 weeks after planting 15 Vinca seeds in peat amended with $\mathrm{Al}_{2}\left(\mathrm{SO}_{4}\right)_{3}$ solutions at $\mathrm{pH} 4$ and infesting peat with either two or five colonized Vinca leaf disks in A and B, two separate experiments. Different letters above bars designate significant differences based on the Waller-Duncan K-ratio test $(\mathrm{K}=100)$. ducted twice. The general linear models procedure was used for data analysis, and treatment differences were determined with a Waller-Duncan K-ratio test $(\mathrm{K}=100)$.

Pore-size distribution analysis. A pore-size distribution analysis was conducted to determine whether the largest water-filled pores at various $\psi_{\mathrm{m}}$ values could accommodate zoospore movement in the peat system. Moist peat was placed in Büchner funnels and packed to a $D_{b}$ of approximately $0.12 \mathrm{~g} \mathrm{~cm}^{-3}$. Plastic bags were placed over each funnel to prevent evaporation. Funnels were brought to saturation for $24 \mathrm{~h}$, equilibrated at either $0,-1.0$, $-2.5,-5.0$, or $-10.0 \mathrm{kPa} \psi_{\mathrm{m}}$ with respect to the peat surface using hanging water columns, and allowed to equilibrate for 2 days. One peat sample was removed from each of four replicate funnels and weighed on an analytical balance. Samples were oven dried for $48 \mathrm{~h}$ at $105^{\circ} \mathrm{C}$, and dry weight was recorded. A soil moisture characteristic was developed by plotting volumetric water content $\left(\mathrm{cm}^{3} / \mathrm{cm}^{3}\right)$ versus $\psi_{\mathrm{m}}$.

A pore-size distribution was calculated by a standard equation (9), with surface tension and density of water taken at $30^{\circ} \mathrm{C}$. The water-filled volume fraction of total pore space was plotted against pore diameter (micrometer).

\section{RESULTS}

Estimation of Al binding capacity. Proton consumption by peat, determined by titrating with $0.05 \mathrm{M} \mathrm{HCl}$, resulted in two pH-buffering regions (Fig. 1). Adsorption of $\mathrm{H}^{+}$was pronounced between $\mathrm{pH} 11$ and 8 and between $\mathrm{pH} 5$ and 3. The proton consumption was calculated as $1.41 \mathrm{mmol} \mathrm{g}^{-1}$ of peat between $\mathrm{pH}$ 11 and 3. Most $\mathrm{H}^{+}$adsorption occurred between $\mathrm{pH} 5$ and 3, with

TABLE 1. Exchangeable aluminum ( $\mathrm{Al})$ and $\mathrm{pH}$ measurements in peat amended with $\mathrm{Al}_{2}\left(\mathrm{SO}_{4}\right)_{3}$ at $\mathrm{pH} 4$ or 6

\begin{tabular}{lcccc}
\hline $\begin{array}{l}\text { Soln. } \\
\mathrm{pH}^{\mathrm{w}}\end{array}$ & $\begin{array}{c}\mathrm{Al} \text { level }(\mathrm{g} \text { of } \\
\mathrm{Al} / \mathrm{g} \text { of peat })^{\mathrm{x}}\end{array}$ & $\begin{array}{c}\text { Initial exchangeable } \\
\mathrm{Al}(\mathrm{mmol} / \mathrm{g} \text { of peat })^{\mathrm{y}}\end{array}$ & $\begin{array}{c}\text { Final exchangeable } \\
\mathrm{Al}(\mathrm{mmol} / \mathrm{g} \text { of peat })^{\mathrm{y}}\end{array}$ & $\mathrm{pH}^{\mathrm{z}}$ \\
\hline 4.0 & 0.0079 & 0.0094 & 0.0079 & 4.61 \\
4.0 & 0.0158 & 0.0615 & 0.0586 & 4.35 \\
6.0 & 0.0079 & 0.0003 & $0.0027^{*}$ & 5.18 \\
6.0 & 0.0158 & 0.0010 & 0.0010 & 5.39 \\
\hline
\end{tabular}

${ }^{\mathrm{w}} \mathrm{Al}_{2}\left(\mathrm{SO}_{4}\right)_{3}$ solution was speciated at $\mathrm{pH} 4.0$ or 6.0 with $1.0 \mathrm{~N} \mathrm{KOH}$.

${ }^{x} \mathrm{Al}$ levels were determined by the amount of $0.05 \mathrm{M} \mathrm{Al}_{2}\left(\mathrm{SO}_{4}\right)_{3}$ added to peat.

${ }^{y}$ Levels of exchangeable Al measured by an extraction with $1.0 \mathrm{M} \mathrm{KCl}$ followed by titration of exchangeable Al according to the method of Yuan (39). * indicates significant difference $(P \leq 0.05)$ between initial and final level of exchangeable Al determined by Student's $t$ test.

${ }^{\mathrm{z}}$ Average $\mathrm{pH}$; measured in 1:2(wt/vol) suspension of peat in $0.01 \mathrm{M} \mathrm{CaCl}_{2}$ (35).

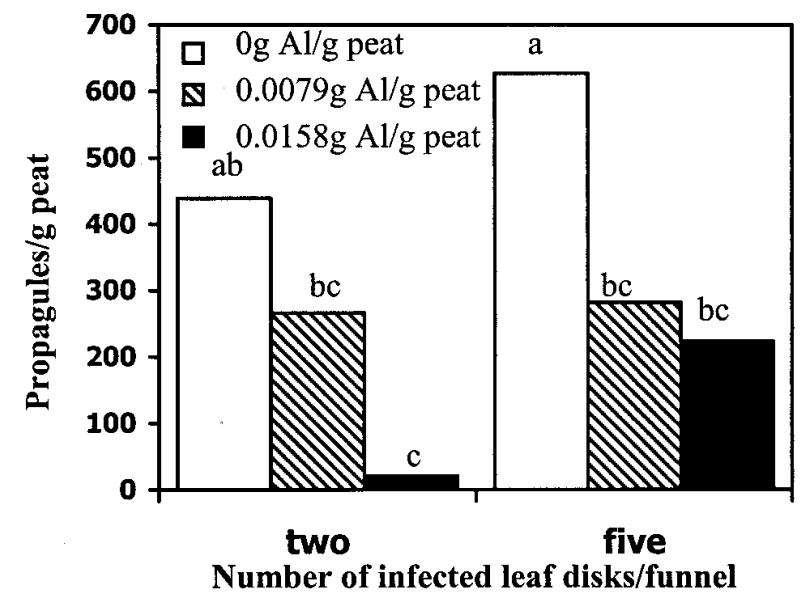

Fig. 3. Assays of Phytophthora parasitica populations were conducted 2 weeks after planting 15 Vinca seeds in peat amended with $\mathrm{Al}_{2}\left(\mathrm{SO}_{4}\right)_{3}$ solutions at pH 6 and infesting peat with either two or five colonized Vinca leaf disks. 
approximately $1.11 \mathrm{mmol} \mathrm{H}^{+}$binding per gram of peat in this region of the curve.

Effects of Al amendment on pathogen populations. Amendment of peat with $0.0158 \mathrm{~g}$ of $\mathrm{Al}$ per gram of peat, applied as $\mathrm{Al}_{2}\left(\mathrm{SO}_{4}\right)_{3}$ solution at $\mathrm{pH} 4$, suppressed pathogen populations in both runs of the experiment, but because inoculum densities differed between runs, results of each test are presented separately (Fig. 2A and B). Analysis of variance (ANOVA) results from the first run of the experiment indicated a significant inoculum level by peat interaction $(P \leq 0.01)$ effect, whereas ANOVA results of the second experiment indicated both an $\mathrm{Al}$ level $(P \leq 0.01)$ and an inoculum level $(P \leq 0.01)$ effect with no interaction. Peat amended with the high level of $\mathrm{Al}$ reduced pathogen populations by $>98 \%$ at the low inoculum level and $>86 \%$ at the high inoculum level compared with the control (Fig. 2A and B). Addition of $\mathrm{Al}_{2}\left(\mathrm{SO}_{4}\right)_{3}$ solution at $\mathrm{pH} 4$ lowered the average $\mathrm{pH}$ from 4.7 (unamended with $\mathrm{Al}$ ) to 4.61 and 4.35 at the low and high $\mathrm{Al}$ levels, respectively (Table 1). No significant differences between initial and final $\mathrm{pH}$ were observed. Peat amended with $\mathrm{Al}_{2}\left(\mathrm{SO}_{4}\right)_{3}$ solution at $\mathrm{pH} 4$ contained an average of $0.0601 \mathrm{mmol}$ exchangeable $\mathrm{Al}$ per gram of peat (Table 1). No statistical differences in stand counts were observed between treatments, and the pathogen was not detected in the uninoculated control treatments.

$P$. parasitica populations were also reduced in peat amended with $\mathrm{Al}_{2}\left(\mathrm{SO}_{4}\right)_{3}$ solution at $\mathrm{pH} 6$ compared with the nonamended control (Fig. 3). There was a significant Al level effect $(P \leq 0.01)$, but an inoculum level effect was not observed. The high Al level ( $0.0158 \mathrm{~g}$ of $\mathrm{Al}$ per gram of peat) reduced pathogen populations by 95 and $65 \%$ at the low and high inoculum levels, respectively. The low Al level (0.0079 $\mathrm{g}$ of Al per gram of peat) reduced the populations by $55 \%$ at the high inoculum level, but populations were similar to the controls at the low inoculum level (Fig. 3). Amendment of peat with $\mathrm{Al}_{2}\left(\mathrm{SO}_{4}\right)_{3}$ solution at $\mathrm{pH} 6$ raised the $\mathrm{pH}$ from 4.7 to 5.18 and 5.39 at the low and high $\mathrm{Al}$ levels, respectively (Table 1). No significant differences between initial and final $\mathrm{pH}$ were observed. Peat contained an average of 0.0015 and $0.001 \mathrm{mmol}$ exchangeable $\mathrm{Al}$ per gram of peat after amendment with the low and high Al levels, respectively (Table 1). No statistical differences in stand counts were observed between treatments, and propagules of $P$. parasitica were not detected in the uninoculated control treatments.

Effect of counter anion. Similar levels of pathogen suppression were observed in the presence of $\mathrm{Cl}^{-}$and $\mathrm{SO}_{4}{ }^{2-}$ at each amendment solution $\mathrm{pH}$ (Table 2). The amendment solution $\mathrm{pH}$, however, had a significant effect on pathogen populations $(P \leq$ 0.05). Exchangeable $\mathrm{Al}$ levels and $\mathrm{pH}$ differed with the $\mathrm{AlCl}_{3}$ and $\mathrm{Al}_{2}\left(\mathrm{SO}_{4}\right)_{3}$ treatments; $\mathrm{AlCl}_{3}$ treatments at $\mathrm{pH} 4$ resulted in higher levels of exchangeable $\mathrm{Al}$ than $\mathrm{Al}_{2}\left(\mathrm{SO}_{4}\right)_{3}$ treatments (Table 2). Peat amended with $\mathrm{AlCl}_{3}$ and $\mathrm{Al}_{2}\left(\mathrm{SO}_{4}\right)_{3}$ solutions at $\mathrm{pH} 6$ contained similar levels of exchangeable Al (Table 2). The initial and final levels of exchangeable $\mathrm{Al}$ were negatively correlated with average $\mathrm{pH}\left(R^{2}=0.86\right)$. For example, the $\mathrm{AlCl}_{3}$ treatment at $\mathrm{pH} 4$ resulted in the lowest $\mathrm{pH}$ (3.62) and the highest level of exchangeable $\mathrm{Al}\left(0.1825 \mathrm{mmol} \mathrm{g}^{-1}\right.$ of peat). The $0.05 \mathrm{M} \mathrm{AlCl}_{3}$ amendment solution also contained the highest $\mathrm{Al}^{3+}$ activity as predicted by the chemical speciation program GEOCHEM-PC (Table 3) (31). This treatment also was toxic to $C$. roseus, resulting in almost total inhibition of seed germination (Table 2). In contrast, peat amended with $\mathrm{Al}_{2}\left(\mathrm{SO}_{4}\right)_{3}$ solution at $\mathrm{pH} 4$ equilibrated at a $\mathrm{pH}$ of 4.12 , resulting in an average exchangeable $\mathrm{Al}$ level of $0.0505 \mathrm{mmol} \mathrm{g}^{-1}$, and seed germination was $75 \%$. Amendment with $\mathrm{AlCl}_{3}$ solution at $\mathrm{pH} 6$ elevated the $\mathrm{pH}$ to 5.64, with an average of $0.0020 \mathrm{mmol}$ exchangeable $\mathrm{Al}$ per gram of peat. Similarly, amendment with $\mathrm{Al}_{2}\left(\mathrm{SO}_{4}\right)_{3}$ solution at $\mathrm{pH} 6$ increased the $\mathrm{pH}$ to 5.34 , with an average exchangeable $\mathrm{Al}$ level of $0.0045 \mathrm{mmol} \mathrm{g}^{-1}$ of peat.

Zoospore movement. The distance between inoculum source and bait affected infection of baits. Twenty-four percent of bait segments were infected at the $0.5-\mathrm{cm}$ distance, but no infection was detected in baits $1.0 \mathrm{~cm}$ from the inoculum source. The duration of flood had no effect on infection of baits.

Soil moisture characteristic/pore-size distribution. Peat had a volumetric water content of $0.97 \mathrm{~cm}^{3} \mathrm{~cm}^{-3}$ at saturation, and $0.58 \mathrm{~cm}^{3} \mathrm{~cm}^{-3}$ upon equilibration at $-2.5 \mathrm{kPa} \psi_{\mathrm{m}}$. The pore-size distribution of the peat medium indicated that at $-2.5 \mathrm{kPa} \psi_{\mathrm{m}}$, $60 \%$ of the total pore space was filled with water (Fig. 4). Therefore, approximately $40 \%$ of the pores are greater than $116 \mu \mathrm{m}$ in diameter, which allows for zoospore motility.

\section{DISCUSSION}

Assuming that $\mathrm{Al}$ binds to carboxylic acid functional groups on peat, the titration of exchangeable acidity of the peat-based medium used in this study provided a quantitative estimation of the

TABLE 3. Activity of $\mathrm{Al}^{3+}$ and sum activity of monomeric $\mathrm{Al}$ species in solutions used to amend peat, as predicted by GEOCHEM-PC

\begin{tabular}{lccc}
\hline Amendment solution $^{\mathrm{w}}$ & $\mathrm{pH}^{\mathrm{x}}$ & $-\log \left(\mathrm{Al}^{3+}\right)^{\mathrm{y}}$ & $-\log \left(\sum \mathrm{mono}\right)^{\mathrm{z}}$ \\
\hline $0.05 \mathrm{M} \mathrm{Al}_{2}\left(\mathrm{SO}_{4}\right)_{3}$ & 4.0 & 6.07 & 6.03 \\
$0.05 \mathrm{M} \mathrm{Al}_{2}\left(\mathrm{SO}_{4}\right)_{3}$ & 6.0 & 9.90 & 7.80 \\
$0.05 \mathrm{M} \mathrm{AlCl}_{3}$ & 4.0 & 3.90 & 4.86 \\
$0.05 \mathrm{M} \mathrm{AlCl}_{3}$ & 6.0 & 9.90 & 7.80 \\
\hline
\end{tabular}

${ }^{\mathrm{v}} \mathrm{Al}$ amendment levels were determined by varying the amount of $\mathrm{Al}_{2}\left(\mathrm{SO}_{4}\right)_{3}$ and $\mathrm{AlCl}_{3}$ solutions added to peat.

w Peat was amended with either an $\mathrm{Al}_{2}\left(\mathrm{SO}_{4}\right)_{3}$ or $\mathrm{AlCl}_{3}$ solution. Al levels were determined by varying the amount of solution added to peat.

$\mathrm{x}$ The $\mathrm{pH}$ of each solution was adjusted to either 4.0 or 6.0 with the addition of $1.0 \mathrm{~N} \mathrm{KOH}$.

${ }^{\mathrm{y}}-\log \left(\mathrm{Al}^{3+}\right)$ in each solution was predicted by GEOCHEM-PC.

${ }^{\mathrm{z}} \sum$ mono $=\left(\mathrm{Al}^{3+}\right)+\left(\mathrm{AlOH}^{2+}\right)+\left(\mathrm{Al}(\mathrm{OH})_{2}^{+}\right)+\left(\mathrm{Al}(\mathrm{OH})_{3}{ }^{0}\right)+\left(\mathrm{Al}(\mathrm{OH})_{4}^{-}\right) . \mathrm{Ac}-$ tivities of each species were predicted by GEOCHEM-PC.

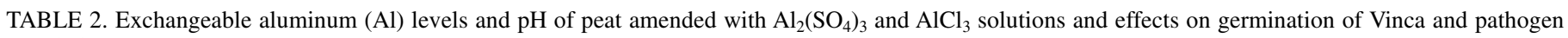
population

\begin{tabular}{|c|c|c|c|c|c|c|}
\hline Al source ${ }^{\mathrm{u}}$ & $\begin{array}{l}\text { Amendment } \\
\text { solution } \mathrm{pH}^{\mathrm{v}}\end{array}$ & $\begin{array}{l}\text { Initial exchangeable Al } \\
(\mathrm{mmol} / \mathrm{g} \text { of peat })^{\mathrm{W}}\end{array}$ & $\begin{array}{l}\text { Final exchangeable Al } \\
(\mathrm{mmol} / \mathrm{g} \text { of peat })^{\mathrm{w}}\end{array}$ & $\mathrm{pH}^{\mathrm{x}}$ & $\%$ Germination $^{\mathrm{y}}$ & $\begin{array}{l}\text { Propagules per } \\
\text { gram of peat }^{\mathrm{z}}\end{array}$ \\
\hline $\mathrm{Al}_{2}\left(\mathrm{SO}_{4}\right)_{3}$ & 4.0 & 0.0510 & 0.0500 & 4.12 & $75 \mathrm{a}$ & $0.75 \mathrm{a}$ \\
\hline $\mathrm{Al}_{2}\left(\mathrm{SO}_{4}\right)_{3}$ & 6.0 & 0.0035 & 0.0055 & 5.34 & $68 \mathrm{a}$ & $21 \mathrm{~b}$ \\
\hline $\mathrm{Al}(\mathrm{Cl})_{3}$ & 4.0 & 0.1865 & 0.1785 & 3.62 & $1.6 \mathrm{~b}$ & $0 \mathrm{a}$ \\
\hline $\mathrm{Al}(\mathrm{Cl})_{3}$ & 6.0 & 0.0035 & $0.0005^{*}$ & 5.64 & $68 \mathrm{a}$ & $29 \mathrm{~b}$ \\
\hline
\end{tabular}

u Peat was amended with either $0.05 \mathrm{M} \mathrm{Al}_{2}\left(\mathrm{SO}_{4}\right)_{3}$ or $\mathrm{Al}(\mathrm{Cl})_{3}$ at $0.0158 \mathrm{~g}$ of $\mathrm{Al}$ per gram of peat.

${ }^{v} \mathrm{Al}_{2}\left(\mathrm{SO}_{4}\right)_{3}$ solution was adjusted to $\mathrm{pH} 4.0$ or 6.0 with $1.0 \mathrm{~N} \mathrm{KOH}$.

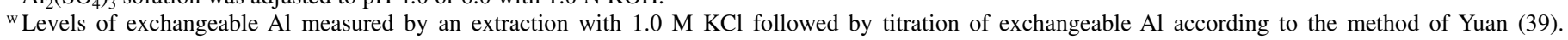

*Significant difference $(P \leq 0.05)$ between initial and final level of exchangeable Al determined by Student's $t$ test.

${ }^{x}$ Average $\mathrm{pH}$; measured in 1:2 (wt/vol) suspension of peat in $0.01 \mathrm{M} \mathrm{CaCl}_{2}$ (35).

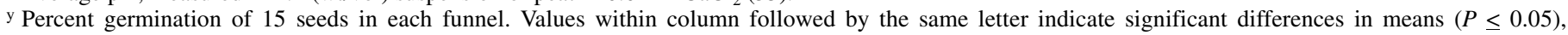
determined by Waller-Duncan K-ratio test.

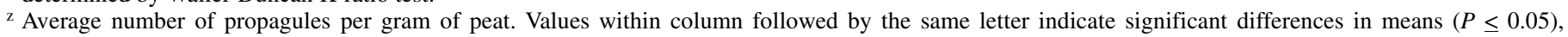
determined by Waller-Duncan K-ratio test. 
peat's potential Al binding capacity (5). Titration of peat from $\mathrm{pH}$ 11 to 3 sequentially protonates these acid groups, first neutralizing the charge of phenolic groups $\left(\mathrm{pK}_{\mathrm{a}} 8\right.$ to 11$)$ and then the carboxylic acid groups $\left(\mathrm{pK}_{\mathrm{a}} 3\right.$ to 6$)$. The presence of specific acid functional groups can be determined by the location of buffer regions on the titration curve (36). The two buffer regions observed in our peat medium corresponded to the $\mathrm{pK}_{\mathrm{a}}$ values of phenolic and carboxylic acids. Because Al binds preferentially to carboxylic acid groups (5), the Al binding capacity is closely related to the acidity titrated between $\mathrm{pH} 6$ and 3. If Al complexation is best modeled by a 1:1 relationship, with $1 \mathrm{~mol} \mathrm{Al}$ binding to 1 mol carboxyl groups (5), the expected Al binding capacity of peat would be $1.11 \mathrm{mmol} \mathrm{g}^{-1}$ of peat, which was the exchangeable acidity titrated between $\mathrm{pH} 6$ and 3 . In this study, the highest added $\mathrm{Al}$ level was $0.585 \mathrm{mmol} \mathrm{Al}$ per gram of peat or about onehalf of the expected Al binding capacity of the peat medium.

The lower levels of exchangeable $\mathrm{Al}$ detected in peat amended with $\mathrm{Al}_{2}\left(\mathrm{SO}_{4}\right)_{3}$ solutions at $\mathrm{pH} 6$ than those at $\mathrm{pH} 4$ may be related to the $\mathrm{Al}$ species distribution and the $\mathrm{pH}$-dependent $\mathrm{Al}$ binding capacity of peat. The $\mathrm{Al}$ species distributions are different in $\mathrm{Al}$ solutions at $\mathrm{pH} 4$ and 6 . At $\mathrm{pH} 4$, over $95 \%$ of total $\mathrm{Al}$ in solution is expected to be in the $\mathrm{Al}^{3+}$ form, but at $\mathrm{pH}$ 6, approximately $80 \%$ is expected in the $\mathrm{Al}(\mathrm{OH})_{2}{ }^{+}$form (23). Bloom and McBride (5) suggest that the hydrolysis species bind more strongly to organic ligands than $\mathrm{Al}^{+3}$. The prevalence of $\mathrm{Al}(\mathrm{OH})_{2}{ }^{+}$and its strong association with carboxylic acid groups may account for the lower levels of exchangeable $\mathrm{Al}$ in treatments amended with $\mathrm{Al}$ solutions at $\mathrm{pH}$ 6. The $\mathrm{pH}$-dependent formation of an $\mathrm{Al}(\mathrm{OH})_{3}$ precipitate may also explain the lower levels of exchangeable $\mathrm{Al}$ in peat amended with $\mathrm{Al}$ solutions at $\mathrm{pH}$ 6. In $\mathrm{pH} 4$ amendment solutions, the amount of total soluble $\mathrm{Al}$ in equilibrium with gibbsite was approximately $10^{-3} \mathrm{M}$, whereas at $\mathrm{pH} 6$, the total soluble $\mathrm{Al}$ was approximately $10^{-6.3} \mathrm{M}$, as predicted by thermodynamics (23). The $\mathrm{pH} 4$ solution was $10^{2}$ times supersaturated with respect to gibbsite, and the $\mathrm{pH} 6$ solution was $10^{5.3}$ times supersaturated with respect to gibbsite. The toxicity of gibbsite to fungi is unknown. Furthermore, peat amended with $\mathrm{Al}$ solutions at $\mathrm{pH} 6$ equilibrated at a higher $\mathrm{pH}$ than peat amended with $\mathrm{Al}$ solutions at $\mathrm{pH}$. The higher $\mathrm{pH}$ may increase the negative surface charge on peat, consequently increasing the Al binding capacity of the medium.

Benson (3) observed suppression of $P$. parasitica in an organic potting medium composed of peat and vermiculite, but unlike

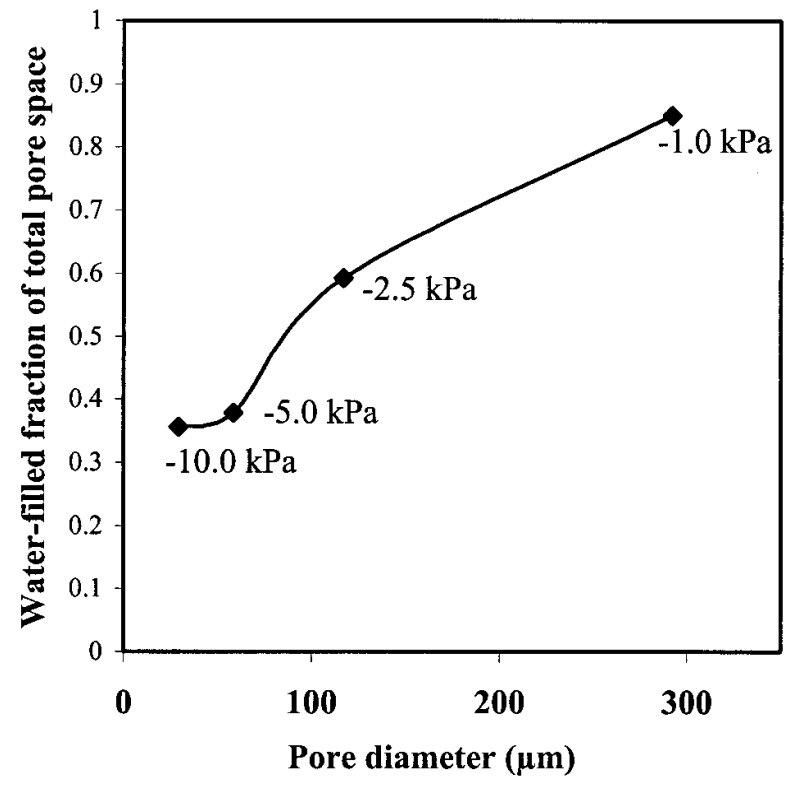

Fig. 4. Pore-size distribution for peat packed to a bulk density of $0.12 \mathrm{~g} / \mathrm{cm}^{3}$ at $30^{\circ} \mathrm{C}$ at selected matric potential values. suppression of soilborne fungi in mineral soils $(21,26,27,29)$, the reduction of pathogen populations occurred with low levels of exchangeable Al. The low levels of exchangeable Al in Benson's system suggest that much of the $\mathrm{Al}$ was complexed with the peat fraction rather than in the exchanger phase of the vermiculite. In our system, the mineral component was excluded to eliminate the cation exchange capacity offered by the vermiculite. Consequently, this work documents suppression of $P$. parasitica in medium containing very low levels of exchangeable Al. Peat amended with $0.0158 \mathrm{~g}$ of $\mathrm{Al}$ per gram of peat as an $\mathrm{Al}_{2}\left(\mathrm{SO}_{4}\right)_{3}$ solution at $\mathrm{pH} 6$, reduced populations of $P$. parasitica by more than $90 \%$ with only $0.0010 \mathrm{mmol}$ exchangeable $\mathrm{Al}$ per gram of peat. The amount of $\mathrm{KCl}$ exchangeable $\mathrm{Al}$ in the peat system is approximately three times lower than levels suppressive to $T$. basicola $(26,27)$ and $P$. infestans (2), and 11 times lower than levels suppressive to $P$. capsici (29) on a volume basis. Studies of Al toxicity to these fungi were conducted either in vitro or in mineral soils, and suppression was directly related to the level of exchangeable $\mathrm{Al}$ or $\mathrm{Al}$ in solution. In contrast, the low level of $\mathrm{KCl}$ exchangeable $\mathrm{Al}$ in the peat system suggests that either solid phase or dissolved complexes of Al ions may be responsible for suppression of $P$. parasitica.

Suppression of pathogens in mineral soils generally occurs at pH 5.2 and below, whereas suppression of $P$. parasitica was observed in Al-amended peat with a $\mathrm{pH}>5.2$. Less than $1 \%$ of the summed total activity of monomeric $\mathrm{Al}$ species was contributed by $\mathrm{Al}^{3+}$ activity in both amendment solutions $\left(\mathrm{AlCl}_{3}\right.$ and $\left.\mathrm{Al}_{2}(\mathrm{SO} 4)_{3}\right)$ at $\mathrm{pH}$ 6, as predicted by GEOCHEM-PC (31). Peat amended with the high level of $\mathrm{Al}$, added at $\mathrm{pH} 6$, equilibrated at $\mathrm{pH}>5.3$. Assuming that surface hydrolysis and hydrolysis of dissolved $\mathrm{Al}$ are the same at a given $\mathrm{pH}$, approximately $90 \%$ of monomeric $\mathrm{Al}$ is expected in the $\mathrm{Al}(\mathrm{OH})_{2}{ }^{+}$species at $\mathrm{pH} 5.3$ (23). The prevalence of $\mathrm{Al}(\mathrm{OH})_{2}{ }^{+}$in the system suggests that ions other than $\mathrm{Al}^{3+}$ were responsible for pathogen suppression. GEOCHEM-PC was not used to model speciation of $\mathrm{Al}$ in the peat system because the predictions do not account for $\mathrm{Al}$ complexes with the soluble organic ligands that would be expected to form in the peat. The relative toxicity of each $\mathrm{Al}$ hydrolysis species to fungi is unknown; however, recent studies indicate that phytotoxicity is correlated with the sum of the activities of monomeric $\mathrm{Al}$ species rather than the activity of $\mathrm{Al}^{3+}$ alone $(18,33)$.

The type of counter anion present $\left(\mathrm{Cl}^{-}\right.$or $\left.\mathrm{SO}_{4}{ }^{2-}\right)$ in each $\mathrm{Al}$ source did not alter suppression of $P$. parasitica. Similarly, Al source, $\mathrm{AlCl}_{3}$ or $\mathrm{Al}_{2}\left(\mathrm{SO}_{4}\right)_{3}$, has no effect on sporangia production of $P$. infestans (2), and multiple stages in the life cycle of $T$. basicola (27). Although both $\mathrm{AlCl}_{3}$ and $\mathrm{Al}_{2}\left(\mathrm{SO}_{4}\right)_{3}$ were effective at reducing populations of $P$. parasitica, amendment of peat with $\mathrm{AlCl}_{3}$ inhibited germination of $C$. roseus; consequently, this source of Al should not be used to amend peat for pathogen suppression. The phytotoxicity observed in peat amended with $\mathrm{AlCl}_{3}$ may be related to the elevated activity of $\mathrm{Al}^{3+}$ and monomeric $\mathrm{Al}$ hydrolysis species in the amendment solution. Sulfate reduces the activities of $\mathrm{Al}$ hydrolysis species by formation of soluble complexes, such as $\mathrm{Al}\left(\mathrm{SO}_{4}\right)^{+}$and $\mathrm{Al}\left(\mathrm{SO}_{4}\right)_{2}{ }^{-}(32,33)$.

Damping-off was not observed in unamended, infested control treatments. Because the same isolate of the pathogen caused damping-off of C. roseus in coarse sand (E. J. Fichtner, unpublished data), it was hypothesized that the physical properties of peat may inhibit movement of zoospores from the inoculum to the seed. The low level of infection in stem segments placed $0.5 \mathrm{~cm}$ from inoculum, and the lack of infection at the $1.0-\mathrm{cm}$ distance suggest that zoospore movement was limited in the peat system.

Zoospore motility is limited by pore size, low $\psi_{\mathrm{m}}$, and lack of continuity of pores (11). Sporangia tend to discharge zoospores within $2 \mathrm{~h}$ of saturation (22), and zoospores remain motile for only a few hours before encysting (12). Because flood duration had no effect on infection of bait segments, the 24-h-saturation period in experiments should have induced zoospore release and provided 
enough time for zoospore movement. Shew (34) reported that duration of saturation had little effect on disease of tobacco caused by $P$. parasitica var. nicotianae, with $100 \%$ infection occurring after only $0.5 \mathrm{~h}$ of saturation.

The pore-size distribution was used to determine whether pore size was a factor limiting zoospore motility in peat. Because zoospores of $P$. cinnamomi swim in a helical pattern with a radius of approximately $110 \mu \mathrm{m}(1)$, an estimated $25 \%$ of the pores in the sieved peat have a diameter large enough to accommodate zoospore movement, assuming that zoospores of $P$. parasitica have a swim radius similar to that of $P$. cinnamomi. Both the prevalence of large pores $(\geq 220-\mu \mathrm{m}$ diameter) and long duration of saturation suggest that zoospore movement was most likely limited by a lack of continuity of large pores in the peat matrix.

Al suppresses plant pathogens in both mineral soils and peatbased potting media; however, the chemical conditions in these systems are very different. In soils high in organic matter, soluble complexation reactions between organic ligands and $\mathrm{Al}$ reduce the activity of $\mathrm{Al}$ in solution. In the peat system, only $0.17 \%$ of the $\mathrm{Al}$ added as $\mathrm{Al}_{2}\left(\mathrm{SO}_{4}\right)_{3}$ solution at $\mathrm{pH} 6(0.0158 \mathrm{~g}$ of $\mathrm{Al}$ per gram of peat) was extractable with $\mathrm{KCl}$. The high $\mathrm{Al}$ binding capacity of peat and the strong association between $\mathrm{Al}$ hydrolysis species and organic ligands, and the predicted presence of an $\mathrm{Al}(\mathrm{OH})_{3}$ precipitate, all suggest that much of the $\mathrm{Al}$ in the peat system was either tightly bound to the organic fraction or in a precipitate of gibbsite. Furthermore, suppression of $P$. parasitica was observed in Alamended peat at $\mathrm{pH}>5.3$, indicating that the species distribution of $\mathrm{Al}$ in the peat system was different than that in suppressive mineral soils $(\mathrm{pH}<5.2)$. The prevalence of $\mathrm{Al}(\mathrm{OH})_{2}{ }^{+}$in peat amended with $\mathrm{Al}_{2}\left(\mathrm{SO}_{4}\right)_{3}$ and $\mathrm{AlCl}_{3}$ solutions at $\mathrm{pH} 6$ suggests that ions other than $\mathrm{Al}^{3+}$ may be responsible for pathogen suppression. Based on the difference in chemical conditions of Al-amended peat and suppressive mineral soils, we speculate that the mechanism of Al-mediated suppression of plant pathogens may be different in the two systems. Future studies, however, will be designed to study the mechanisms of suppression in both mineral and organic media. The low levels of exchangeable $\mathrm{Al}$ in the peat system may enable its integration into disease management programs as a suppressive component in potting media for plant container culture. Future studies also are planned to determine the role of organically complexed $\mathrm{Al}$ and monomeric $\mathrm{Al}$ hydrolysis species in the suppression of $P$. parasitica.

\section{LITERATURE CITED}

1. Allen, R. N., and Newhook, F. J. 1973. Chemotaxis of zoospores of Phytophthora cinnamomi to ethanol in capillaries of soil pore dimensions. Trans. Br. Mycol. Soc. 61:287-302.

2. Andrivon, D. 1995. Inhibition by aluminum of mycelial growth and of sporangial production and germination in Phytophthora infestans. Eur. J. Plant Pathol. 101:527-533.

3. Benson, D. M. 1993. Suppression of Phytophthora parasitica on Catharanthus roseus with aluminum. Phytopathology 83:1303-1308.

4. Benson, D. M. 1995. Aluminum amendment of potting mixes for control of Phytophthora damping-off in bedding plants. HortScience 30:14131416.

5. Bloom, P. R., and McBride, M. B. 1979. Metal ion binding and exchange with hydrogen ions in acid-washed peat. Soil Sci. Soc. Am. J. 43:687-692.

6. Bloom, P. R., McBride, M. B., and Weaver, R. M. 1979. Aluminum organic matter in acid soils: Buffering and solution aluminum activity. Soil Sci. Soc. Am. J. 43:488-493.

7. Bruckert, S. 1970. Influence des composes organiques solubles sur la pedogenese en milieu acide: I. Etudes de terrain. Ann. Agron. 21:421-452.

8. Coleman, T., and Thomas, G. W. 1967. The basic chemistry of soil acidity. Pages 1-41 in: Soil Acidity and Liming. R. W. Pearson and R. Adams, eds. American Society of Agronomy, Madison, WI.

9. Danielson, R. E., and Sutherland, P. L. 1986. Porosity. Pages 443-460 in: Methods of Soil Analysis, Part 1. Physical and Mineralogical Methods. 2nd ed. A. Klute, ed. American Society of Agronomy, Madison, WI.

10. Deczky, K., and Langford, C. H. 1978. Application of water nuclear magnetic relaxation times to study of metal complexes of the soluble soil organic fraction fulvic acid. Can. J. Chem. 56:1947-1951.
11. Duniway, J. M. 1976. Movement of zoospores of Phytophthora cryptogea in soils of various textures and matric potentials. Phytopathology 66:877-882.

12. Duniway, J. M. 1983. Role of physical factors in the development of Phytophthora diseases. Pages 175-188 in: Phytophthora, Its Biology, Taxonomy, and Pathology. D. C. Erwin, S. Bartnicki-Garcia, and P. H. Tsao, eds. The American Phytopathological Society, St. Paul, MN.

13. Firestone, M. K., Killham, K., and McColl, J. G. 1983. Fungal toxicity of mobilized soil aluminum and manganese. Appl. Environ. Microbiol. 46:758-761.

14. Furuya, H., Takahashi, T., and Matsumoto, T. 1999. Suppression of Fusarium solani f. sp. phaseoli on bean by aluminum in acid soils. Phytopathology 89:47-52.

15. Hargrove, W. L., and Thomas, G. W. 1982. Conditional formation constants for aluminum-organic matter complexes. Can. J. Soil Sci. 62:571-575.

16. Hargrove, W. L., and Thomas, G. W. 1982. Titration properties of Alorganic matter. Soil Sci. 134:216-225.

17. Hsu, P. H. 1989. Aluminum hydroxides and oxyhydroxides. Pages 331378 in: Minerals in Soil Environments. J. B. Dixon and S. B. Weed, eds. Soil Science Society of America, Madison, WI.

18. Hue, N. V., Craddock, G. R., and Adams, F. 1986. Effect of organic acids on aluminum toxicity in subsoils. Soil Sci. Soc. Am. J. 50:28-34.

19. Kannwischer, M. E., and Mitchell, D. J. 1978. The influence of a fungicide on the epidemiology of black shank of tobacco. Phytopathology 68:1760-1765.

20. Ko, W. H., and Hora, F. K. 1972. Identification of an $\mathrm{Al}$ ion as a soil fungitoxin. Soil Sci. 113:42-45.

21. Kobayashi, N., and Ko, W. H. 1985. Nature of suppression of Rhizoctonia solani in Hawaiian soils. Trans. Br. Mycol. Soc. 84:691-694.

22. MacDonald, J. D., and Duniway, J. M. 1978. Influence of the matric and osmotic components of water potential on zoospore discharge in Phytophthora. Phytopathology 68:751-757.

23. Marion, G. M., Hendricks, D. M., Dutt, G. R., and Fuller, W. H. 1976. Aluminum and silica solubility in soils. Soil Sci. 121:76-85.

24. Martin, A. E., and Reeve, R. 1958. Chemical studies of podzolic illuvial horizons. III. Titration curves of organic-matter suspensions. J. Soil Sci. 9:89-100.

25. Meyer, J. R., and Shew, H. D. 1991. Development of black root rot on burley tobacco as influenced by inoculum density of Thielaviopsis basicola, host resistance, and soil chemistry. Plant Dis. 75:601-605.

26. Meyer, J. R., and Shew, H. D. 1991. Soils suppressive to black root rot of burley tobacco, caused by Thielaviopsis basicola. Phytopathology 81:946-954.

27. Meyer, J. R., Shew, H. D., and Harrison, U. J. 1994. Inhibition of germination and growth of Thielaviopsis basicola by aluminum. Phytopathology 84:598-602.

28. Mizuno, N., and Yoshida, H. 1993. Effect of exchangeable aluminum on the reduction of potato scab. Plant Soil 155/156:505-508.

29. Muchovej, J. J., Maffia, L. A., and Muchovej, R. M. C. 1980. Effect of exchangeable soil aluminum and alkaline calcium salts on the pathogenicity and growth of Phytophthora capsici from green pepper. Phytopathology 70:1212-1214.

30. Orellana, R. G., Foy, C. D., Fleming, A. L. 1975. Effect of soluble aluminum on growth and pathogenicity of Verticillium albo-atrum and Whetzelinia sclerotiorum from sunflower. Phytopathology 65:202-205.

31. Parker, D. R., Norvell, W. A., and Chaney, R. L. 1995. GEOCHEM-PC: A chemical speciation program for IBM and compatible personal computers. Pages 263-269 in: Soil Chemical Equilibrium and Reaction Models. R. H. Loeppert, P. P. Schwab, and S. Goldberg, eds. Soil Science Society of America, Madison, WI.

32. Ritchie, G. S. P. 1989. The chemical behavior of aluminum, hydrogen, and manganese in acid soils. Pages 1-60 in: Soil Acidity and Plant Growth. A. D. Robson, ed. Academic Press, San Diego, CA.

33. Sanzonowicz, C., Smyth, T. J., and Israel, D. W. 1998. Calcium alleviation of hydrogen and aluminum inhibition of soybean root extension from limed soil into acid subsurface solutions. J. Plant Nutr. 21:785-804.

34. Shew, H. D. 1983. Effects of soil matric potential on infection of tobacco by Phytophthora parasitica var. nicotianae. Phytopathology 73:1160-1163.

35. Smiley, R. W., and Cook, R. J. 1972. Use and abuse of the soil pH measurement. Phytopathology 62:193-194.

36. Sparks, D. L. 1995. Chemistry of soil organic matter. Pages 53-80 in: Environmental Soil Chemistry. Academic Press, San Diego, CA.

37. Stevenson, F. J., and Ardakani, M. S. 1972. Organic matter reactions involving micronutrients in soils. Pages 79-114 in: Micronutrients in Agriculture. J. J. Mortvedt, P. M. Giordano, and W. L. Lindsay, eds. Soil Science Society of America, Madison, WI.

38. Thomas, G. W. 1975. The relationship between organic matter content and exchangeable aluminum in acid soils. Soil Sci. Soc. Am. Proc. 39:591.

39. Yuan, T. L. 1959. Determination of exchangeable hydrogen in soils by a titration method. Soil Sci. 88:164-167. 